\title{
Intellectual Property and Acceptable Models in Technology Transfer in Albanian Economy
}

\author{
Associated Professor Evelina Bazini \\ University "Ismail Qemali" Vlore, Albania, Faculty of Economy \\ evelina.bazini@univlora.edu.al
}

\section{Doi:10.5901/ajis.2015.v4n3s1p369}

\begin{abstract}
Technology transfer is a part of wider activity in a certain company. First of all is connected with production and business procedure of the company. However, technology is only one of the ways to realize expected goals. Technology transfer can be presented in different ways and the most important transfers are the ones by license, joint-venture, long-term production cooperation, carrying out the investment works and franchising. Albania is facing with two challenges regarding technology transfer. The first one refers to the ability of effectively creating proper channels for technology transfer which will result in the conversion of the country's research capacity and human capital into an asset for economic growth, competitiveness, and rising standards of living. The second is to enhance competitiveness and productivity in low and medium domestic technology sectors.
\end{abstract}

Keywords: intellectual property, technology, technology transfer..

\section{Introduction}

Definition of technology given by the World Intellectual Property Organization (WIPO) describes it as a "systematic knowledge for product manufacture and service provision in industry, farming and commercial fields".

Technology transfer enables to technology giver to exploit the results of his research work and in that way to realize large financial impacts, and to technology receiver enables to, without using his own financial resources, gain finished technological solutions in order to increase the business success and competitiveness on the market.

\section{Intellectual Property ${ }^{1}$}

Intellectual property (IP) is a term used to describe a group of intangible products like ideas, inventions, technologies, artworks, music and literature. Different way of introducing IP is to describe it as a commercial application of imaginative thought to solving a technical or artistic challenge. The objective of protecting intellectual property is to encourage the creation of valuable ideas and to protect them from being stolen. The four most common types of intellectual property are:

Copyright (): Gives the author exclusive rights to reproduce the copyrighted material. Copyrights can be in published or unpublished works, e.g., original literary, musical, dramatic or artistic works, computer programs and other matter. Copyright protects the expression of ideas, but not the ideas themselves.

Trade Secret: A broad term to cover secret information that is defined by how it is treated and protected. It provides an owner of the information with a market advantage over its competitors. To enforce trade secret actions, an owner must show that the trade secret has been maintained in a way that reasonably anticipates preventing others from learning about it. Unlike patents, trademarks, and copyrights, there is no registration of a trade secret with a government agency.

Trademark ${ }^{\mathrm{T}}$, ( $\mathrm{B}$ : A logo, word, slogan, symbol or design that distinguishes a product or a service. Trademarks protect corporate identity and can be legally registered.

Patent: Provides inventors and those with rights to inventions the exclusive right for a limited period of time to prevent anyone else from making, using or selling the invention. Patents are granted on machines, articles of manufacture (devices), compositions of matter (materials), processes (methods), and improvements of any of these. Patents are filed in each country individually. 


\section{Technology and Technology Transfer}

Definition of technology given by World Intellectual Property Organization (WIPO) refers to "the systematic knowledge for product manufacture and service provision in industry, farming and commercial fields. Different authors agree that there is not such an easy thing to define technology transfer since the process itself is a complex one (Robinson 1988; Spivey et al. 1997). Other authors define technology transfer taking in consideration the process of movement of technology from one entity to another (Souder et al. 1990; Ramanathan 1994). The process of transfer is considered to be successful if it is possible of for the receiving entity, to have an effective utilization of the technology transferred and easy assimilate it (Ramanathan, 1994). The transfer may involve physical assets, know-how, and technical knowledge (Bozeman, 2000). The transfer and diffusion of technology has been a topic of research for over fifty years (see Ryan and Gross 1943, for example). It is generally recognized that adoption of a new technology starts off slowly (phase I) and at around 20\% adoption by the target population the adoption rate increases rapidly (phase II). This period of rapid adoption is followed by a saturation of the technology and a very slow increase (phase III) in the cumulative number of adopters (Valente 1995). This gives rise to an S-shaped curve as shown below in Figure 1.

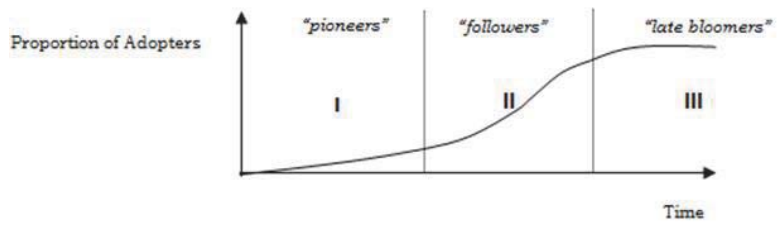

Figure 1. Typical S-Shaped Cumulative Adoption Curve for Innovation Diffusion

Researchers have tried to explain why this rapid adoption occurs as a means of facilitating the rapid adoption of an innovation. Valente (1995) emphasizes that diffusion is a social process and can be analyzed by focusing on individuals (threshold models) or social systems (critical mass models). Both approaches recognize the need to analyze 'who talks to whom?' and 'who influences whom?

\subsection{Types \& Scope of Technology Transfer Subjects ${ }^{2}$}

Assets that have economic value can be classified into tangible assets, which have specific form, and intangible assets, which do not have specific form. Here, the technologies subject to transfer are classified as intangible assets. The concept and scope of intangible asset technology is very wide and flexible. In the narrow sense it means the manufacturing technique on the manufacturing site, confidential technology, know-how etc, and in the wider sense it also means the entire intellectual property that has economic value

Technologies subject to technology transfer are as follow :

- registered patents, utility models, designs, and trademarks;

- (non-registered) know-how including technological information or data of corporations, technological services, technological support etc.;

- other protective rights of computer software, semiconductor chips etc.

Table 1. Technology transfer subjects

\begin{tabular}{|l|l|}
\hline Classification & Details of rights \\
\hline Industrial property rights & Patents, utility models, designs, trademarks \\
\hline Copyrights & Property rights, personnel rights, neighboring rights \\
\hline \multirow{3}{*}{ Neo-intellectual property rights } & Advanced industrial property rights: semiconductor chip circuit design rights, life science technology rights \\
\cline { 2 - 2 } & Industrial copyrights: computer programs \& software \\
\cline { 2 - 2 } & Information property rights: trade secrets (know-how) database rights, new media rights \\
\hline
\end{tabular}

2 See www.technology4sme.net 


\section{The Role of Intellectual Property during Technology Transfer}

When technology transfer occur, the role of intellectual property is of a special importance, sometimes compared to the "currency" that provide the access to it. Intellectual property is used by firms for the purpose of finding new business partners or creating new strategic alliances. These new relationships make possible the connection of different teams with complementary technologies, skills and managerial techniques. IP sometimes is considered as funding sources for the company since it can be sold to other parties interested on it. Different countries encourage their firms to invest in buying advanced foreign technologies. Other benefits from the intellectual property rights consist on the facilitation that a firm has in the identification of her technology and of it them self. Intellectual property rights also present many challenges in technology transfer specially for products developed by public institutions, in the context of the increasing trend for public sector institutions themselves to pursue intellectual property protection of their research outcomes ${ }^{3}$.

\section{Acceptable Models of Technology Transfer in Albania Economy}

One of the basic problems of Albanian economy is technological left-behind what results with insufficient competitiveness. Albanian economy needs technological renewal. Albania can gain modern technology in two ways:

○ through development of its scientific-research potential and transferring the created technology into economy,

$\circ$ gaining technology from abroad

Gaining technology from the proper resources should be the base for technological development. However, proper researching depend on invested financial resources.

Considering the present situation of Albanian economy and characteristics of particular models of technology transfer, we can suggest models of technology transfer which could increase technological level of Albanian economy. Models of technology transfer are ranked by the level of acceptance for Albanian economy:

- Gaining technology from the proper researching

- Joint-venture

- Cooperation

- Investment work from abroad

- Franchising

- Getting licenses

The most acceptable model of technology transfer is the one what transfers and commercializes from domestic institutions, and is the result of domestic researchers. After that follows joint -venture. Foreign partner will in joint-venture invest modern technology because on that depends his business success. Cooperation is especially interest because to domestic partner, based on technology from foreign partner, ensures long-term sale of his products. These models should be dominate models of technology transfer what should realize faster connection with developed countries

\section{Concluding Remarks}

Different ways of providing technology transfer refers to use of license, joint-venture, long-term production cooperation, carrying out the investment works and franchising. All these transfer models do not ensure the competitiveness of the technology receiver.

Very important is the staff expertness in choosing technology and it is very important to consider the life stage of technology. The most acceptable model of technology transfer is the one transferred and commercialized from domestic companies and is the result of domestic researchers. After that is technology transfer through joint-venture and production cooperation. These models should be the primary models of technology transfer in Albanian economy in order to achieve faster technological connection with economies of developed countries.

Albania is facing with two challenges regarding technology transfer. The first one refers to the ability of effectively creating proper channels for technology transfer which will result in the conversion of the country's research capacity and human capital into an asset for economic growth, competitiveness, and rising standards of living. The second is to enhance competitiveness and productivity in low and medium domestic technology sectors.

A suggested way for technological development in Albania may be the observation of the knowledge produce 
outside. Albanian enterprises ability to compete is effected by the process of absorption of knowledge and their knowledge diffusion capability.

\section{References}

American Economic Review, Papers and Proceedings, May, pp. 244-250.

Arrow, K. (1969). Classificatory note on the production and transmission of technological knowledge.

Barnes, G. (1999). GPS technology transfer in Albania: History, progress and future strategies.

Basberg, B., (1987). Patents and the measurement of technological change: A survey of the literature, Research Policy, North Holland.

Battersby, G. J., Grimes, C. W., (1996). An Insider's Guide to Royalty Rates: A Comprehensive Survey of Royalty Rates and Licensed Products, Kent Press, Stamford.

Bello, K., Bazini, E. (2008). Proceedings of the International Conference "Economic \& Social Challenges and Problems, 2008. Volume II, $247-256$.

Berman, B., (2002). From ideas to asets: Investing wisely in Intellectual Property, John Wiley \& Sons, Inc, USA

Bierman, H., Jr., Smidt, S., (1993). The Capital Budgeting Decision: Economic Analysis of Investment Projects, Macmillan Publishing Company, New York.

Bodie, Z., Kane, A, Marcus, A J., (1997). Investments, McGraw-Hill, New York.

Bonbright, 1., (1965). The Valuation of Property, The Michie Company, Charlottesville, VA Boston.

Bozeman, B., 2000. Technology transfer and public policy: A review of research and theory. Research

Chen, M., 1996. Managing International Technology Transfer. Thunderbird Series in International

Cooke, Philip; Leydesdorff, Loet, 2006, Regional development in the knowledge - based economy: The construction of advantage. Journal of Technology Transfer, 31; 5 - 15 .

Corporate and Research-based Spin-offs in the European Union, http://www.jre.es (27.12.2005)

Domi, E. 2010. Albanian's general directorate of customs report. Inter -regional symposium enforcement of IPRs. 2-3 November 2010, Prague.

Dosi, G., 1988. The nature of the innovation process. In G. Dosi, G., Ed. Technical Change and Economic Theory. Printer Publications, London.

Driouehi, Ahmed; Azelmad, El Mustapha; Anders, Gary, 2006, An econometric analysis of the role of knowledge in economy performance. Journal of Technology Transfer, 31; 241 - 255.

Engineering Management, 39(1), pp. 13-21.

Gibbs, A, De Matteis, B., (2003). Essentials of patents. John Wiley \& Sons, Inc., USA

Gibson, D.V. and Rogers, E.M., 1994. R\&D Collaboration on Trial: The Microelectronics and Computer Technology Consortium. Harvard Business School Press, Boston.

http://www.research.uwaterloo.ca (14.02.2006.)

http://www.sistemac.srce.hr

Licensing: Corporate Strategies for Maximizing Value, John Wiley \& Sons, Inc., New York.

Lundquist, G., 2003. A rich vision of technology transfer technology value management. Journal of Technology Transfer, 28(3-4), pp. 284

Management. International Thompson Press, London.

Mansfield, E., 1975. East-West technological transfer issues and problems, international technology transfer: Forms, resource requirements, and policies. American Economic Review, 65(2), pp. 372-376.

Miller, A. R., Davis, M. H., (2000). Intellectual pro erty, patents, trademarks and copyright, West Group, USA.

More research for Europe, 2002, Commission of the European communities, Brussels

Osman-Gani, A.A.M. 1999. International technology transfer for competitive advantage: A conceptual analysis of the role of HRD. Competitiveness Review, 9, pp. 9.

Palmintera, Diane, 2005, Accelerating Economy Development Through University Technology Transfer, Hartford, Innovation Associates Inc.

Phillips, R.G., 2002. Technology business incubators: How effective as technology transfer mechanisms. Technology in Society, 24, pp. 299-316.

Policy, 29, pp. 627-655.

Poltorak, A. I., Lerner, P. J., (2002). Essentials of intellectual property. John Wiley \& Sons, Inc., USA.

Ramanathan, K. An Overview of Technology Transfer and Technology Transfer Models.

Ramanathan, K., 2000. A Taxonomy of International Technology Transfer Modes. Proceedings of the Portland International Conference on Management and Technology, July 29-August 2, Portland, US.

Ramanathan, K., 2001, E-strategies for technological capability development, Proceedings of the Portland International Conference on Management and Technology, July 29-August 2, Portland, US.

Rivette, K. G., Kline, D., (2000). Rembrandts in the Attic, Harvard Business School Press.

Ryan, R and N. Gross (1943). "The Diffusion of Hybrid Seed Corn in two lowa Communities." Rural Sociology, 8(1), pp. 15-24.

Spivery, W.A., Munson, J.M., Nelson M.A. and Dietrich, G.B., 1997. Coordinating the technology transfer and transition of information 
technology: A phenomenological perspective, IEEE Transactions on Engineering Management, 44(4), pp. 359-366.

Stingi, A. 2005. What is intellectual property?, CARNET,

Sullivan, P., Fox, S., (1996). Establishing an Out-Licensing Activity in Technology.

Technology, Transfer \& Licensing. University of Waterloo, Third International Conference on Operations and Quantitative Management, Sydney, 17-20 December.

Tornatzky, Louis, 2000, Building state economies by promoting university- industry technology transfer, Washington, National Governors' Association.

Valente, T.W. (1995). Network Models of the Diffusion of Innovation. Hampton Press, Inc., New Jersey.

Zhao, L.M. and Reisman, A., 1992. Toward meta research on technology transfer. IEEE Transactions on

www.cbd.int

www.ictpi09.org.pt

www.research.uwaterloo.ca

www.technology4sme.net

www.business-asia.net

www.wipo.int

www.ignou.ac.in

prudenslawfirm.com

confcontact.com

www.internationalconference.com.my 